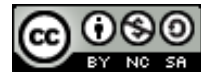

https://doi.org/10.31743/abmk.13258

KATARZYNA KALISZ* - WARSZAWA

\title{
OPRACOWANIE FOTOGRAFII W NARODOWYM ARCHIWUM CYFROWYM. UWAGI DO ZESPOLÓW I ZBIORÓW O TEMATYCE KOŚCIELNEJ
}

\section{Streszczenie}

W zasobie Narodowego Archiwum Cyfrowego są przechowywane fotografie wytworzone i zgromadzone przez agencje fotograficzne, czołowych polskich fotografów zawodowych, fotoreporterów lub fotografów amatorów. Fotografie te mogą stanowić samodzielne całości, bądź być częścią zespołów aktowych. $\mathrm{W}$ artykule poruszono zagadnienia związane z zespołami (zbiorami) składającymi się wyłącznie z dokumentacji fotograficznej. Akty normatywne wydane przez Naczelnego Dyrektora Archiwów Państwowych ustalają sposób postępowania z materiałami archiwalnymi. Są to: Zarządzenie nr 7 z dnia 30 stycznia 2018 r. w sprawie ewidencjonowania zasobu archiwalnego $\mathrm{w}$ archiwach państwowych oraz Zarządzenie $\mathrm{nr} 8 \mathrm{z}$ dnia 30 stycznia 2018 r. w sprawie inwentaryzacji materiałów archiwalnych oraz sporządzania i zatwierdzania elektronicznych inwentarzy archiwalnych dla zespołów (zbiorów) w archiwach państwowych. W Zarządzeniu nr 34 Naczelnego Dyrektora Archiwów Państwowych z dnia 9 września 2019 r. w sprawie zasad porządkowania i inwentaryzacji dokumentacji fotograficznej $\mathrm{w}$ archiwach państwowych wskazano w szczególności na sposób postępowania $\mathrm{z}$ fotografiami.

Dokumentacja fotograficzna powinna posiadać ewidencję. W przypadku gdy stan zachowania zdjęć budzi wątpliwości, a także jest przeszkodą w digitalizacji, należy skonsultować się z dyplomowanym konserwatorem i w razie konieczności przeprowadzić konserwację. Inwentaryzacja i digitalizacja wraz z przepakowaniem do opakowań zabezpieczających to kolejne etapy pracy nad zespołem (zbiorem) archiwalnym. Podczas prac inwentaryzacyjnych oceniana jest wartość archiwalna materiałów. Wstęp do inwentarza zawiera informacje dopełniające posiadaną wiedzę o materiałach w zespole (zbiorze) oraz o ich

\footnotetext{
* Katarzyna Kalisz - mgr historii sztuki, kierownik Oddziału Zbiorów Fotograficznych, Narodowe Archiwum Cyfrowe w Warszawie

e-mail: katarzyna.kalisz@nac.gov.pl

https://orcid.org/ 0000-0002-0943-4812
} 
twórcy (autorze kolekcji). Do prac ewidencyjnych czy inwentaryzacyjnych najlepiej wykorzystać Zintegrowany System Informacji Archiwalnej (ZoSIA).

W Narodowym Archiwum Cyfrowym są przechowane zespoły i zbiory poświęcone tematyce kościelnej. W artykule omówiono je z uwagi na interesującą zawartość, metodę opracowania i opisu, problematykę autorskich praw majątkowych, możliwość wykorzystania przez użytkowników, a także ocenę wartości archiwalnej. Są to głównie: 3/19/0 Zbiór fotografii dotyczących obchodów kościelnych Tysiąclecia Chrztu Polski, 3/43/0 Archiwum fotograficzne Stanisława Porębskiego, 3/76/0 Zbiór fotografii dotyczących uroczystości beatyfikacyjnych księdza Jerzego Popiełuszki w Warszawie, 3/78/0 Zbiór kopii cyfrowych fotografii dotyczących opactwa Benedyktynów w Tyńcu, 3/82/0 Kolekcja Mariana Romaniuka dotycząca Prymasa Polski Kardynała Stefana Wyszyńskiego.

Słowa kluczowe: dokumentacja fotograficzna; zdjęcia; fotografie archiwalne; opracowanie fotografii; archiwum fotograficzne; inwentaryzacja fotografii; jednostka archiwalna; obiekt fotograficzny; autorskie prawa majątkowe; ocena wartości archiwalnej

\section{Wprowadzenie}

W zasobie fotograficznym Narodowego Archiwum Cyfrowego znajduje się ponad 15 milionów zdjęć wytworzonych i zgromadzonych przez agencje fotograficzne o zasięgu krajowym (prywatne przed 1939 r. i państwowe po 1945 r.) $)^{1}$, czołowych polskich fotografów zawodowych działających w XX wieku², fotoreporterów $w^{3}$ lub fotografów amatorów $w^{4}$. Materiały te trafiały do zasobu archiwum na podstawie ustawowych przejęć, zakupów, darów i depozytów. Wraz z wejściem w życie w styczniu 2018 r. zarządzenia nr 7 Naczelnego Dyrektora Archiwów

${ }^{1}$ Zob. zespoły 3/1/0 Koncern Ilustrowany Kurier Codzienny - Archiwum Ilustracji (19101939), 3/4/0 Centralna Agencja Fotograficzna (1944-1992) oraz 3/39/0 Wojskowa Agencja Fotograficzna (1945-1991).

${ }^{2}$ Są to m.in. zespoły: 3/42/0 Archiwum fotograficzne Edwarda Hartwiga (1945-1982), 3/51/0 Archiwum fotograficzne Zbyszka Siemaszki (1950-1999), 3/53/0 Archiwum fotograficzne Lecha Zielaskowskiego (1954-2000), 3/131/0 Archiwum fotograficzne Henryka Poddębskiego (19201939). Od 2014 r. Narodowe Archiwum Cyfrowe publikowało w postaci tradycyjnej i elektronicznej monograficzne wydawnictwa albumowe poświęcone spuściznom tych fotografów: Warszawa Siemaszki. Fotografie z Narodowego Archiwum Cyfrowego, Warszawa 2014, https://www.nac.gov. pl/pub/Warszawa_Siemaszki/mobile/index.html (dostęp: 4.12.2021); PRL Rutowskiej. Fotografie z Narodowego Archiwum Cyfrowego, Warszawa 2015, https://www.nac.gov.pl/pub/PRL_Rutowskiej/mobile/index.html (dostęp: 4.12.2021); Narcyz Witczak-Witaczyński, Warszawa 2016, https:// www.nac.gov.pl/pub/Narcyz_Witczak-Witaczynski/mobile/index.html\#p=1 (dostęp 4.12.2021); Niepodległa Poddębskiego, Warszawa 2017, https://www.nac.gov.pl/wp-content/uploads/2017/11/ NAC-Henryk-Poddebski-eBook.pdf (dostęp: 4.12.2021); Wojciech Tuszko - fotograf, Warszawa 2020, https://www.nac.gov.pl/wp-content/uploads/2015/05/nac-TUSZKO-1.0.1-www.pdf (dostęp: 4.12.2021).

${ }^{3}$ Jest to m.in. 3/40/0 Archiwum Grażyny Rutowskiej ([1944] 1946-2002 [2004-2015]).

${ }^{4}$ Są to m.in.: 3/120/0 Archiwum fotograficzne Jana Schrama (1900-1939), 3/125/0 Archiwum fotograficzne Andrzeja Urbańczyka (1895-1945, 1957-1958, 1977-1978, 1983-1984), 3/135/0 Archiwum fotograficzne Stefana Czarneckiego (1916-1936). 
Państwowych w sprawie ewidencjonowania zasobu archiwalnego w archiwach państwowych $^{5}$ stan liczbowy zasobu Narodowego Archiwum Cyfrowego jest stopniowo pomniejszany w wyniku przeprowadzanej korekty ewidencji ${ }^{\text {: obec- }}$ nie to nieco poniżej 10 milionów jednostek archiwalnych fotografii. Dzieje się tak za sprawą zmiany definicji fotograficznej jednostki archiwalnej. Zgodnie z nieaktualną już definicją jednostki, a obowiązującą od wejścia w życie wskazówek metodycznych wprowadzonych decyzją Naczelnego Dyrektora Archiwów Państwowych w 2006 r. $^{7}$, jednostkę archiwalną w zespole (zbiorze) fotografii stanowiły wszystkie elementy utrwalonego zapisu danego obrazu (negatyw, pozytyw, plik danych, wydruk) ${ }^{8}$. Tak zdefiniowana jednostka była równocześnie podstawową jednostką miary stanu ewidencyjnego dla zasobu fotograficznego?. Obecnie obowiązująca definicja jednostki archiwalnej ${ }^{10}$ jest spójna dla wszystkich rodzajów i postaci dokumentacji archiwalnej, w tym dokumentacji fotograficznej. W myśl tej definicji jednostkę archiwalną tworzy dokument lub grupa dokumentów połączonych ze sobą według określonych kryteriów przed lub po ich przejęciu przez archiwum państwowe i stanowiących fizyczną i logiczną całość albo jedną $\mathrm{z}$ tych całości ${ }^{11}$. Fotografie przechowywane w archiwum mogą stanowić samodzielne całości (w zespołach lub zbiorach), tworząc m.in. spuścizny, kolekcje, archiwa rodzinne albo mogą być częścią zespołów aktowych. W artykule zostanie poruszona tematyka związana z zespołami (zbiorami) składającymi się wyłącznie z dokumentacji fotograficznej, zawierającymi fotografie o tematyce kościelnej.

${ }^{5}$ Zarządzenie nr 7 Naczelnego Dyrektora Archiwów Państwowych z dnia 30 stycznia 2018 r. w sprawie ewidencjonowania zasobu archiwalnego w archiwach państwowych https://www.archiwa.gov.pl/files/zarzadzenia_NDAP/zarz7_2018.pdf (dostęp: 4.10.2021).

${ }^{6}$ Tamże, par. 7 ust. 1.

${ }^{7}$ Decyzja nr 8 Naczelnego Dyrektora Archiwów Państwowych z dnia 24 kwietnia 2006 r. w sprawie wprowadzenia wskazówek metodycznych dotyczących zasad opracowania fotografii w archiwach państwowych, zmieniona decyzją Nr 16 Naczelnego Dyrektora Archiwów Państwowych z dnia 25 lipca 2006 r. https://www.archiwa.gov.pl/images/docs/akty_normatywne/ Dec 8 2006.pdf (dostęp: 4.12.2021).

${ }^{8}$ Tamże, Definicje podstawowych pojęć. Załącznik.

${ }^{9}$ Zgodnie z nieaktualnymi obecnie wskazówkami metodycznymi dotyczącymi zasad opracowania fotografii w archiwach państwowych wydanych decyzją nr 8 Naczelnego Dyrektora Archiwów Państwowych z dnia 24 kwietnia 2006 r. jednostką stanowiącą pozycję w inwentarzu była jednostka inwentarzowa, czyli temat definiowany jako: „Jedna lub wiele fotografii, połączonych ze sobą elementem chronologicznym, tj. wykonanych w tym samym lub zbliżonym czasie i połączonych logicznie, gdy utrwalony na nich obraz przedstawia określone wydarzenie, zjawisko, osobę lub przedmiot". Od czasu wprowadzenia tych wskazówek temat (jednostka inwentarzowa) nie stanowił podstawy do określania stanu ewidencji zasobu fotograficznego.

${ }^{10}$ Określenie ,jednostka archiwalna” zostało ujednolicone dla wszystkich rodzajów dokumentacji, w tym dokumentacji fotograficznej, w zarządzeniu nr 7 Naczelnego Dyrektora Archiwów Państwowych z dnia 30 stycznia 2018 r., par. 7 ust. 1 do 4.

${ }^{11}$ Tamże, par. 7 ust. 1. 


\section{Postępowanie z fotografiami według przepisów archiwów państwowych}

Naczelny Dyrektor Archiwów Państwowych wydał dwa akty normatywne wskazujące sposób postępowania z materiałami archiwalnymi. To uniwersalne przepisy przygotowane dla każdego rodzaju dokumentacji archiwalnej, i tym samym wykorzystywane także do pracy z fotografią archiwalną. Są nimi zarządzenie nr 7 z dnia 30 stycznia 2018 r. w sprawie ewidencjonowania zasobu archiwalnego w archiwach państwowych i zarządzenie nr 8 z dnia 30 stycznia 2018 r. w sprawie inwentaryzacji materiałów archiwalnych oraz sporządzania i zatwierdzania elektronicznych inwentarzy archiwalnych dla zespołów (zbiorów) w archiwach państwowych. Oba normatywy wiążą się z prowadzeniem prac w Zintegrowanym Systemie Informacji Archiwalnej (ZoSIA), będącym - darmowym dla wszystkich użytkowników - narzędziem utrzymywanym, modernizowanym i rozbudowywanym przez Narodowe Archiwum Cyfrowe. Jest ono wykorzystywane przez wszystkie archiwa państwowe. Stosują je również instytucje kultury ${ }^{12}$ i instytucje kościelne ${ }^{13}$, które zdecydowały się na jego wdrożenie - ogółem 108 instytucji. Przywołane normatywy wydają się tak skonstruowane, że archiwum również w przypadku niestosowania ZoSIA może je wykorzystać z pożytkiem na potrzeby prowadzonych prac. Trzeci normatyw, o którym trzeba wspomnieć, to dedykowane fotografiom zarządzenie nr 34 Naczelnego Dyrektora Archiwów Państwowych z dnia 9 września 2019 r. w sprawie zasad porządkowania i inwentaryzacji dokumentacji fotograficznej w archiwach państwowych ${ }^{14}$. Należy je analizować w połączeniu z zarządzeniami dotyczącymi ewidencjonowania i inwentaryzowania materiałów archiwalnych. Treść tych wszystkich zarządzeń można odnaleźć na stronie domowej Naczelnej Dyrekcji Archiwów Państwowych w zakładce Prawo archiwalne - akty normatywne ${ }^{15}$ oraz w Dzienniku Urzędowym Naczelnej Dyrekcji Archiwów Państwowych ${ }^{16}$.

Fotografie, jak i inne rodzaje dokumentacji, powinny posiadać ewidencję. W przypadku braku jakiegokolwiek spisu należy go koniecznie sporządzić, środki ewidencyjne ${ }^{17}$ odzwierciedlają bowiem aktualny stan zasobu archiwalnego ${ }^{18}$. Przygotowując ewidencję zespołów czy zbiorów zdjęciowych, w pierwszej kolejności trzeba sformować jednostkę archiwalną, czyli podstawową jednostkę miary materiałów archiwalnych. Jest nią jedna lub wiele fotografii stanowiących fizyczną

${ }^{12} \mathrm{~Np}$. Fundacja Kultury i Dziedzictwa Ormian Polskich, Muzeum Narodowe w Krakowie.

${ }^{13}$ Np. Zgromadzenie Zmartwychwstania Pańskiego w Rzymie, Klasztor Sióstr Karmelitanek Bosych w Krakowie.

${ }^{14}$ Zarządzenie nr 34 Naczelnego Dyrektora Archiwów Państwowych z dnia 9 września 2019 r. w sprawie zasad porządkowania i inwentaryzacji dokumentacji fotograficznej w archiwach państwowych, https://ndap.bip.gov.pl/dziennik-urzedowy/dziennik-urzedowy-2019.html (dostęp: 4.12.2021).

${ }^{15}$ Dokumenty dostępne na dedykowanej stronie: https://www.archiwa.gov.pl/pl/706-akty-normatywne-naczelnego-dyrektora-archiw (dostęp: 4.10.2021).

${ }^{16}$ Zob. https://ndap.bip.gov.pl/dziennik-urzedowy/ (dostęp: 13.12.2021).

${ }^{17}$ Zob. zarządzenie nr 7 Naczelnego Dyrektora Archiwów Państwowych z dnia 30 stycznia 2018 r., par. 4. Dokument odnosi się bezpośrednio do ZoSIA, archiwum kościelne może jednak dostosować tę informację do miejscowych potrzeb i warunków.

${ }^{18}$ Tamże, par. 5 ust. 1. 
lub logiczną całość bądź jedną z tych całości ${ }^{19}$. Pod względem fizycznym może to być pojedyncza odbitka fotograficzna, slajd lub grupa obiektów w formie scalonej, np. rolka negatywu, album fotograficzny, pudełko, koperta z odbitkami. W przypadku fotografii cyfrowych jednostki archiwalne formuje się podobnie stanowi ją jeden plik lub folder z plikami. Logiczną całość może tworzyć np. fotoreportaż z jednego wydarzenia, seria portretów jednej lub kilku osób, zdjęcia tego samego budynku na zewnątrz i wewnątrz.

Uformowanym jednostkom należy nadać sygnaturę i zatytułować. Tytuł może być oryginalny, tj. nadany przez twórcę, ale jeśli brak adnotacji, trzeba go samodzielnie utworzyć, przy czym musi być on zwięzły i treściwy. Określenie czasu powstania materiałów to kolejny element opisu ewidencyjnego. Często można jedynie wskazać ramy czasowe, np. daty aktywności twórcy materiałów archiwalnych. Konieczne przy tym jest określenie rodzaju opisywanej dokumentacji. Po przeprowadzeniu wymienionych wyżej prac materiały, o ile istnieje techniczna możliwość, należy zeskanować, zwłaszcza gdy są to zdjęcia zapisane na negatywach. Z pewnością ułatwi to identyfikację osób, zdarzeń, odczytanie najdrobniejszych szczegółów, a przede wszystkim - opracowywanie materiałów.

Jeśli stan zachowania zdjęć budzi wątpliwości lub jest przeszkodą w digitalizacji, przydatna będzie konsultacja $\mathrm{z}$ dyplomowanym konserwatorem $\mathrm{i}$ ewentualna naprawa przez specjalistę, czy zabezpieczenie przed dalszą degradacją w ramach przygotowania do skanowania. Podstawowy zakres prac koniecznych do przeprowadzenia na tym etapie obejmuje głównie ich odkurzenie ${ }^{20}$. Tu też będzie sposobność do oceny technicznych atrybutów obrazu, np. zdjęcie nieostre, poruszone. Po odwołaniu się do kryteriów oceny wartości archiwalnej danego materiału będzie można odrzucić ujęcie albo - mając świadomość niedoskonałości obrazu - zachować je. Należy też podkreślić, że nie można dopuścić do zniszczenia oryginalnych nośników, które już zostały zdigitalizowane. Jest to źródło i będzie się do niego wracać, aby weryfikować wiedzę o nim (np. analizować napisy na odwrocie odbitki lub kolejność klatek na negatywie) lub wykonać skan $\mathrm{w}$ większym formacie.

Inwentaryzacja polega na takim opisaniu jednostek archiwalnych mających już ewidencję, aby umożliwić ich identyfikację oraz uzyskać podstawowe informacje na temat ich zawartości i formy ${ }^{21}$. Podczas inwentaryzacji powstaje inwentarz sporządzany odrębnie dla każdego zespołu (zbioru) archiwalnego. Inwentarz ten jest spisem materiałów archiwalnych wchodzących w skład zespołu (zbioru) archiwalnego zawierającym elementy rozpoznawcze materiałów oraz dane

19 Tamże, par. 7 ust. 1.

${ }^{20}$ Zarządzenie nr 14 Naczelnego Dyrektora Archiwów Państwowych z dnia 31 sierpnia 2015 r. w sprawie digitalizacji zasobu archiwalnego archiwów państwowych, par. 2 ust. 12, https://www. archiwa.gov.pl/images/docs/akty_normatywne/zarz_14-2015.pdf (dostęp: 3.10.2021).

${ }^{21}$ Zarządzenie nr 8 Naczelnego Dyrektora Archiwów Państwowych z dnia 30 stycznia 2018 r. w sprawie inwentaryzacji materiałów archiwalnych oraz sporządzania i zatwierdzania elektronicznych inwentarzy archiwalnych dla zespołów (zbiorów) w archiwach państwowych, par. 2 ust. 2, https://www.archiwa.gov.pl/files/zarzadzenia_NDAP/zarz8_2018.pdf (dostęp: 3.10.2021). 
o inwentaryzowanym zespole (zbiorze) archiwalnym ${ }^{22}$. Inwentaryzację poprzedza rozpoznanie materiałów archiwalnych w zespole (zbiorze), czyli zapoznanie się $\mathrm{z}$ ich treścią (przy materiałach negatywowych szczególnie pomocna będzie digitalizacja), sprawdzenie i weryfikacja oryginalnych opisów pozostawionych przez twórcę, porównanie kolejnych egzemplarzy odbitek z tym samym obrazem ${ }^{23}$, nadanie układu. Kolejne działania zależą od stanu uporządkowania materiałów archiwalnych, które znalazły się w archiwum. Niekiedy prace sprowadzą się jedynie do skorygowania układu przygotowanego przez twórcę (autora).

Przed rozpoczęciem inwentaryzacji fotografii bardzo ważna jest ocena ich wartości archiwalnej. Kluczowe przy tym jest szczegółowe zapoznanie się z opracowywanymi materiałami, m.in. pod względem treści, stanu zachowania, powtarzalności ujęć, jakości technicznej obrazu. Kryteria oceny wartości archiwalnej są podobne we wszystkich rodzajach dokumentacji. Przy fotografiach jednak istotne wydają się jeszcze kryteria wartości artystycznej, rangi autora, unikatowości techniki wykonania fotografii itp. Podczas inwentaryzacji należy zwrócić uwagę, czy wśród materiałów fotograficznych znajdują się te, które - pomimo zapisu na nośniku fotograficznym lub zwyczajowego uznania za fotografie - nie są dokumentacją fotograficzną, np. karty pocztowe, reprodukcje dokumentacji innego rodzaju, jak aktowa, ulotna, zapisana w formie mikroform, fotokopii i skanów.

W następnym etapie prac formuje się jednostki archiwalne. Często tworzy się je, uwzględniając wspomniane związki logiczne pomiędzy obrazami. Wśród elementów opisu jednostki w inwentarzu należy zwrócić uwagę na jej identyfikator. Każdy z poszczególnych elementów identyfikatora dokładnie wskazuje jej miejsce w zasobie archiwum. Składa się on z numeru identyfikacyjnego zespołu, identyfikatora liczbowego serii, a niekiedy podserii ${ }^{24}$, sygnatury jednostki, niezmiennie określającej kolejność jednostki archiwalnej w zespole (zbiorze) ${ }^{25}$. Sama sygnatura może być rozbudowana o numer strony w albumie fotograficznym oraz numer obiektu w danej jednostce. W przypadku jednostek wielozdjęciowych warto sporządzać opis do każdego pojedynczego obiektu, jeżeli zdjęcia charakteryzują się szczególnymi cechami - mają wysoką wartość treściową, osoby na nich przedstawione zajmują szczególne miejsce $\mathrm{w}$ historii, dokumentują miejsca już nieistniejące albo o gruntownie zmienionym wyglądzie. Kolejne elementy opisu jednostki to tytuł, który powinien być zwięzły i jak najpełniej odzwierciedlać jej treść oraz daty wykonania fotografii przyporządkowanych do jednostki. W przypadku zdjęć niedatowanych bardzo często czas ich powstania jest jedynie szacowany. Przy określaniu daty należy zwrócić uwagę na najdrobniejsze szczegóły zarejestrowane na obrazie, takie jak rodzaje tablic rejestracyjnych samochodów czy przedmioty gospodarstwa domowego. Chronologię tego typu elementów za-

${ }^{22}$ Tamże, par. 2 ust. 4-5.

${ }^{23}$ Jeśli dwie fotografie są bardzo podobne do siebie, ale nie identyczne, to znaczy, że zostały wykonane z różnych negatywów i nie można ich liczyć jako jednego i tego samego obrazu.

${ }^{24}$ Formowanie serii i podserii omówione zostało w zarządzeniu nr 8 Naczelnego Dyrektora Archiwów Państwowych z dnia 30 stycznia 2018 r., par. 5.

${ }^{25}$ Tamże, par. 3 ust. 1. 
pisanych na obrazie potrafią identyfikować pasjonaci, warto więc korzystać z ich pomocy na tematycznych portalach społecznościowych.

Podczas sporządzania inwentarza należy zwrócić szczególną uwagę na problem autorstwa zdjęćc ${ }^{26}$. Tutaj istotne są nie tylko informacje związane $\mathrm{z}$ imieniem i nazwiskiem autora, lecz także $\mathrm{z}$ ewentualną datą jego śmierci oraz spadkobiercami. W przypadku braku wiedzy na temat pochodzenia zdjęć, niezbędne jest zamieszczenie informacji o ograniczeniu ich rozpowszechniania. Przejmując do archiwum fotografie od ich autora lub właścicieli nośników i praw (mogących swoje prawa udokumentować), warto sporządzić umowę zabezpieczającą zarówno interesy prawno-autorskie ich twórcy lub jego spadkobierców, jak i archiwum. Treść umowy będzie zależeć od ustaleń stron.

Wśród informacji zamieszczanych $\mathrm{w}$ inwentarzu na uwagę zasługuje blok dotyczący nośnika fotograficznego, czyli formy wewnętrznej materiałów ${ }^{27}$. Sporządzenie dokładnego opisu nośników fotograficznych jest możliwe i na poziomie opisywanej jednostki (w przypadku różnorodnej pod względem nośników jednostki wielozdjęciowej należy przygotować listę wszystkich występujących w niej rodzajów nośników), i - analogicznie - na poziomie obiektu fotograficznego, a więc każdej z fotografii należącej do danej jednostki archiwalnej. Zdarza się, że ten sam obraz został zapisany na negatywie i na oryginalnej odbitce pozytywowej. Należy wtedy połączyć oba nośniki w jednym rekordzie opisu w inwentarzu. $\mathrm{Na}$ odbitce trzeba zapisać numer odpowiadającego jej negatywu, aby w razie potrzeby można go było szybko odszukać. Negatywy mogą być zanumerowane od 1 do $n$, lub oznaczone sygnaturą jednostki, w której zostały zinwentaryzowane ${ }^{28}$.

W przypadku albumu fotograficznego jednostka będzie uformowana ze względu na jego fizyczność. Umieszczone w nim fotografie mogą zostać opisane jako obiekty. Karty albumu paginuje się i przy formułowaniu identyfikatora każdej z fotografii wskazane jest, aby podawać numer strony, na której znajduje się dany obiekt fotograficzny ${ }^{29}$. Podczas digitalizacji albumów - oprócz pojedynczych fotografii - warto skanować całe strony albumu, oczywiście przy zachowaniu najwyższego stopnia ostrożności. Udostępniając zainteresowanym osobom skany kart, unika się przeglądania oryginału, na którym sporządzono opisy oraz nadano określony układ na stronie zamieszczonym w nim odbitkom pozytywowym.

Nie zaleca się cięcia filmów negatywowych małoobrazkowych (w formacie $24 \times 36 \mathrm{~mm}$ ) na pojedyncze klatki. Złudne jest wrażenie o łatwiejszym operowaniu podczas prowadzonych prac pojedynczą klatką. Skanowanie takich elementów jest kłopotliwe, gdyż z racji niewielkich rozmiarów materiał łatwiej się odkształca, może też dojść do utraty części informacji zapisanych przy krawędziach obrazu. Ponadto tak pocięta błona ma większe tendencje do deformacji przy nieodpowiednich warunkach przechowywania, co również skutkuje problemami przy skanowaniu i przyczynia się do szybszej destrukcji nośnika.

${ }^{26} \mathrm{O}$ poszczególnych elementach opisu jednostki archiwalnej oraz obiektu zdjęciowego związanych z informacją o autorze i prawach majątkowych zob. tamże, par. 10 pkt. 21-23 i 26.

${ }^{27}$ Tamże, par. 10 pkt 8 .

${ }^{28}$ Tamże, par. 8 ust. 5 .

${ }^{29}$ Tamże, par. 9. 
Aby dopełnić informacji w inwentarzu, należy przygotować do niego wstęp, w którym - zgodnie z zarządzeniem nr 8 Naczelnego Dyrektora Archiwów Państwowych z dnia 30 stycznia 2018 r. ${ }^{30}$ - znajdą się: dzieje twórcy/biografia autora materiałów, opis zawartości zespołu (zbioru), informacja o udostępnianiu, status zespołu (otwarty, zamknięty), bibliografia, dzieje zespołu (zbioru) archiwalnego, informacja o digitalizacji jednostek archiwalnych, informacje o częściach zespołu (zbioru) przechowywanych poza archiwum, metody opracowania zespołu (zbioru), pole uwag. Warto też indeksować lub tagować materiały archiwalne. W tym zadaniu pomóc może zarządzenie nr 3 z dnia 26 stycznia 1974 r. Naczelnego Dyrektora Archiwów Państwowych w sprawie sporządzania indeksów do inwentarzy archiwalnych ${ }^{31}$. Chociaż zostało ogłoszone niemal 50 lat temu, wydaje się pomocne w codziennej pracy archiwisty. Samo indeksowanie, czy też tagowanie, jest niezmiernie przydatne przy wyszukiwaniu informacji, w tym wypadku obrazów. Najlepszy w tym celu jest słownik haseł pomagający ujednolicić rekordy. Lokalny słownik oferuje ZoSIA - wygodne narzędzie wyświetlające podpowiedzi haseł: od najczęściej do najrzadziej występujących w inwentarzach archiwum.

Do prac ewidencyjnych czy inwentaryzacyjnych najlepiej wykorzystać wspomniany Zintegrowany System Informacji Archiwalnej. Łączy on w sobie możliwości katalogowania różnych rodzajów dokumentacji, takich jak dokumentacja aktowa, fotograficzna, ulotna, kartograficzna i inne. Jeśli nie ma możliwości skorzystania z tego systemu, inwentarz warto przygotować w arkuszu kalkulacyjnym. W przyszłości będzie możliwa - w przypadku podjęcia stosownych decyzji migracja danych do ZoSIA.

\section{Fotografie o tematyce kościelnej w zasobie Narodowego Archiwum Cyfrowego}

Zespoły i zbiory fotograficzne poświęcone tematyce kościelnej są przechowane również w Narodowym Archiwum Cyfrowym. Ta część jego zasobu nie została jeszcze całościowo opracowana. Pewne zespoły i zbiory o wskazanej tematyce mają inwentarze lub ewidencje sporządzone według wskazówek metodycznych obowiązujących przed wprowadzeniem zmian w latach $2018^{32}$ i $2019^{33}$. Prowadzone są jednak prace nad korektą ewidencji według obecnie obowiązujących przepisów. Poniżej zostaną zaprezentowane wszystkie zespoły i zbiory o tematyce kościelnej przechowywane w Narodowym Archiwum Cyfrowym. Są one złożone wyłącznie lub niemal wyłącznie $\mathrm{z}$ fotografii.

1) Zbiór fotografii dotyczących obchodów kościelnych Tysiąclecia Chrztu Polski $^{34}$ (1966; nr zespołu 3/19/0) to - po przeprowadzeniu korekty ewidencji we-

${ }^{30}$ Tamże, par. 6 ust. 1 pkt 3.

${ }^{31}$ Zarządzenie nr 3 z dnia 26 stycznia 1974 r. Naczelnego Dyrektora Archiwów Państwowych w sprawie sporządzania indeksów do inwentarzy archiwalnych, https://www.archiwa.gov.pl/files/ zarzadzenia_NDAP/zarz3_1974.pdf (dostęp: 3.10.2021).

${ }^{32}$ Zarządzenie nr 7 Naczelnego Dyrektora Archiwów Państwowych z dnia 30 stycznia 2018 r. oraz Zarządzenie nr 8 Naczelnego Dyrektora Archiwów Państwowych z dnia 30 stycznia 2018 r.

${ }^{33}$ Zarządzenie nr 34 Naczelnego Dyrektora Archiwów Państwowych z dnia 9 września 2019 r.

${ }^{34}$ Zob. https://www.szukajwarchiwach.gov.pl/zespol/-/zespol/55720 (dostęp: 3.10.2021). 
dług obowiązujących zasad ${ }^{35}$ - 25 jednostek archiwalnych, na które składa się 590 obiektów fotograficznych ${ }^{36} \mathrm{w}$ postaci odbitek pozytywowych. Ewidencja w tym przypadku jest już dostosowana do obecnych wymogów. Dokumentacja fotograficzna z tego ogólnopolskiego wydarzenia została zgromadzona przez episkopat Polski. Zdjęcia wykonali różni twórcy wytypowani przez poszczególne kurie biskupie. Nie było stałej ekipy fotoreporterskiej lub specjalnej komórki powołanej do obsługi fotograficznej uroczystości na terenie kraju, często do tego zadania wyznaczano lokalnych fotoreporterów. Zdjęcia przedstawiają duchowieństwo, osoby cywilne biorące udział w uroczystościach kościelnych, jak i sesjach naukowych, obiekty sakralne wraz z wyposażeniem. Fotografie posiadają oryginalne opisy sporządzone w sekretariacie prymasa. Po zakończonych obchodach Tysiąclecia Chrztu Polski do sekretariatu prymasa spłynęły serwisy z poszczególnych diecezji. Dnia 26 czerwca 1973 r. Maria Sułek - archiwistka i siostrzenica kard. Stefana Wyszyńskiego - przekazała nieodpłatnie do Archiwum Dokumentacji Mechanicznej ${ }^{37} 591$ odbitek pozytywowych ${ }^{38}$, które otrzymała z episkopatu Polski $^{39}$. W każdej z jednostek umieszczono dokumentację fotograficzną obchodów w jednej miejscowości, jednostki ułożono chronologicznie. Opisy sporządzono na poziomie obiektów, aby jak najbardziej uszczegółowić treść ze względu na wagę wydarzeń. Jest to zasadne również w odniesieniu do wskazówek metodycznych ${ }^{40}$, które weszły w życie w 2019 r.

2) Archiwum fotograficzne Stanisława Porębskiego ${ }^{41}$ (1955-1956; nr zespołu 3/43/0) zawiera zdjęcia dokumentujące pobyt kard. S. Wyszyńskiego podczas internowania w Komańczy. Zostały zapisane na negatywach w formacie $36 \times$ $24 \mathrm{~mm}$ oraz $60 \times 90 \mathrm{~mm}$. Zespół składa się ze 172 jednostek archiwalnych, w których zinwentaryzowano 192 fotografie. Są tu również odbitki, prawdopodobnie reprodukcje, z fotografiami rodziny Sułków - krewnych S. Wyszyńskiego. Autor zdjęć, ks. Stanisław Porębski (1909-1978, fot. sygn. 3/43/0/0/61/1) był proboszczem parafii w Komańczy, kapelanem sióstr nazaretanek, zaś w czasie internowania kard. Stefana Wyszyńskiego należał do wąskiego grona jego najbliższych powierników. Towarzyszył mu w nabożeństwach, modlitwach, podczas spacerów i wycieczek, zwłaszcza nad jezioro Duszatyn i okolice. W tym

${ }^{35}$ Inwentarz w ZoSIA to obecnie - po przeprowadzeniu korekty ewidencji dostosowującej dane o tym zbiorze do obowiązujących przepisów, ale jeszcze przed jego zatwierdzeniem - elektroniczny inwentarz roboczy. Przy okazji tych prac jest bowiem prowadzona melioracja zbioru mająca na celu poprawienie przeprowadzonego kilkadziesiąt lat temu opracowania. W związku z przedłużającym się stanem pandemii prace jeszcze nie zostały zakończone.

${ }^{36}$ Przed przeprowadzeniem korekty ewidencji zbiór liczył 591 jednostek archiwalnych.

${ }^{37}$ Archiwum to było poprzednikiem Narodowego Archiwum Cyfrowego.

${ }^{38} \mathrm{~W}$ trakcie prac melioracyjnych w zespole zweryfikowano liczbę obiektów - jedna z odbitek okazała się być kolejnym egzemplarzem tego samego obrazu.

${ }^{39}$ Informacje zawarte we wstępie do inwentarza zbioru 3/19/0. Zob. Inwentarz zbioru Tysiaclecie Chrztu Polski [Obchody kościelne], oprac. A. Potemkowska, Warszawa [b.r., mps].

${ }^{40}$ Zarządzenie nr 34 Naczelnego Dyrektora Archiwów Państwowych z dnia 9 września 2019 r., par. 11.

${ }^{41}$ Zob. https://www.szukajwarchiwach.gov.pl/zespol/-/zespol/55741 (dostęp: 3.10.2021). 
czasie powstał zestaw zdjęć obrazujący pobyt S. Wyszyńskiego w Komańczy, wykonany przez jednego autora, w ciągu jednego roku. Kilka fotografii rodziny kardynała pochodzi z czasów wcześniejszych. Jego siostrzenica, wspomniana M. Sułek i inni członkowie rodziny odwiedzali wuja w czasie odosobnienia. Wizyty te zostały udokumentowane na zdjęciach. Fotografie przekazała do archiwum w 2000 r. Maria Sułek ${ }^{42}$, która przez wiele lat pracowała w Archiwum Dokumentacji Mechanicznej przy opracowaniu fotografii. Te cenne materiały znalazły się w jej posiadaniu po uwolnieniu kard. Wyszyńskiego i jego powrocie do Warszawy.

Z uwagi na to, że rok 2021 ustanowiono Rokiem Kardynała Stefana Wyszyńskiego ${ }^{43}$, zespół $\mathrm{nr}$ 3/43/0 poświęcony tej szczególnej osobie duchownej wydaje się niezwykle interesujący. Zapisano tu bowiem wyjątkowy czas internowania, zaś kardynał został pokazany w otoczeniu odwiedzającej go rodziny, fotografie mają prywatny charakter. Można zobaczyć na nich uśmiechniętego duchownego (fot. sygn. 3/43/0/0/33/1), w swobodnych ujęciach (fot. sygn. 3/43/0/0/89/1, fot. sygn. 3/43/0/0/90/1), nawet rozpromienionego (fot. sygn. 3/43/0/0/101/1). Wśród zdjęć wykonanych przez ks. S. Porębskiego jest wiele podobnych ujęć: domu nazaretanek (fot. sygn. 3/43/0/0/123/1, fot. sygn. 3/43/0/0/124/1), towarzyszy kard. S. Wyszyńskiego podczas wędrówek (fot. sygn. 3/43/0/0/135/1, fot. sygn. 3/43/0/0/136/1), wielokrotnie powtarzanych zdjęć krajobrazu (fot. sygn. 3/43/0/0/172/1, fot. sygn. 3/43/0/0/122/1) oraz flory i fauny. Przeprowadzając prace melioracyjne zespołu, wiele takich zdjęć przeznaczono do brakowania i rozpoczęto obowiązującą w tamtym czasie procedurę. Żadna z 49 zgłoszonych do brakowania fotografii (ok. $20 \%$ materiałów w zespole) ostatecznie nie została zniszczona. W 2010 r. Centralna Komisja Archiwalnej Oceny Dokumentacji nie wyraziła zgody na brakowanie, potwierdzając wartość historyczną ${ }^{44}$. Zaważyło kryterium wydarzenia historycznego oraz znaczenia historycznego przedstawionej osoby, a także otaczających ludzi w tym wyjątkowym czasie. Na zachowanych zdjęciach przedstawione zostały nie tylko postaci, lecz także krajobraz, las, budynki i jako kontekst wyjątkowych wydarzeń, mogą mieć dla badaczy pierwszorzędne znaczenie.

${ }^{42}$ Archiwum Dokumentacji Mechanicznej. Przewodnik po zasobie fotografii 1840-2004, oprac. J. Boniecki, Warszawa 2005, s. 213.

${ }^{43}$ Uchwała Sejmu Rzeczypospolitej Polskiej z dnia 27 listopada 2020 r. w sprawie ustanowienia roku 2021 Rokiem Kardynała Stefana Wyszyńskiego (M.P. z 2020 r. poz. 1156).

${ }^{44}$ Pismo z dnia 7 stycznia 2010 r. (sygn. NAC-0011-11/09) i dalsza korespondencja w aktach sprawy w Archiwum Zakładowym Narodowego Archiwum Cyfrowego. 


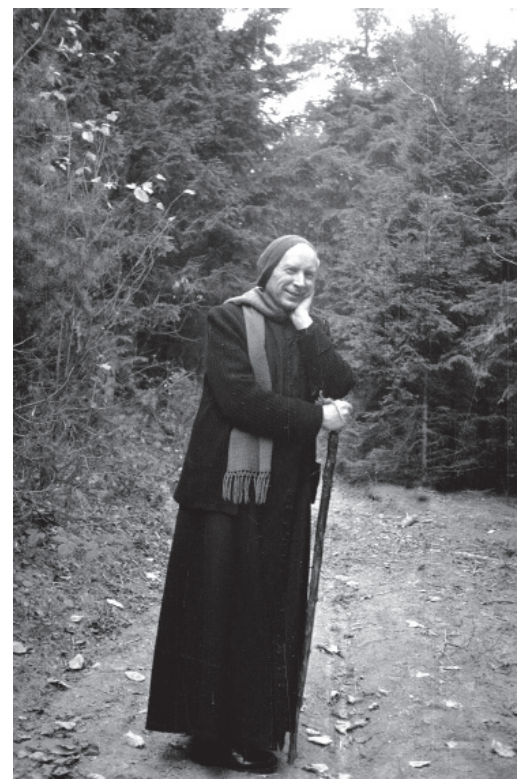

Il. 1. Kard. Stefan Wyszyński na spacerze,

Komańcza 1956. Fot. Stanisław Porębski Źródło: Narodowe Archiwum Cyfrowe, Prymas Polski Stefan Wyszyński podczas internowania w Komańczy, sygn. 3/43/0/0/33/1

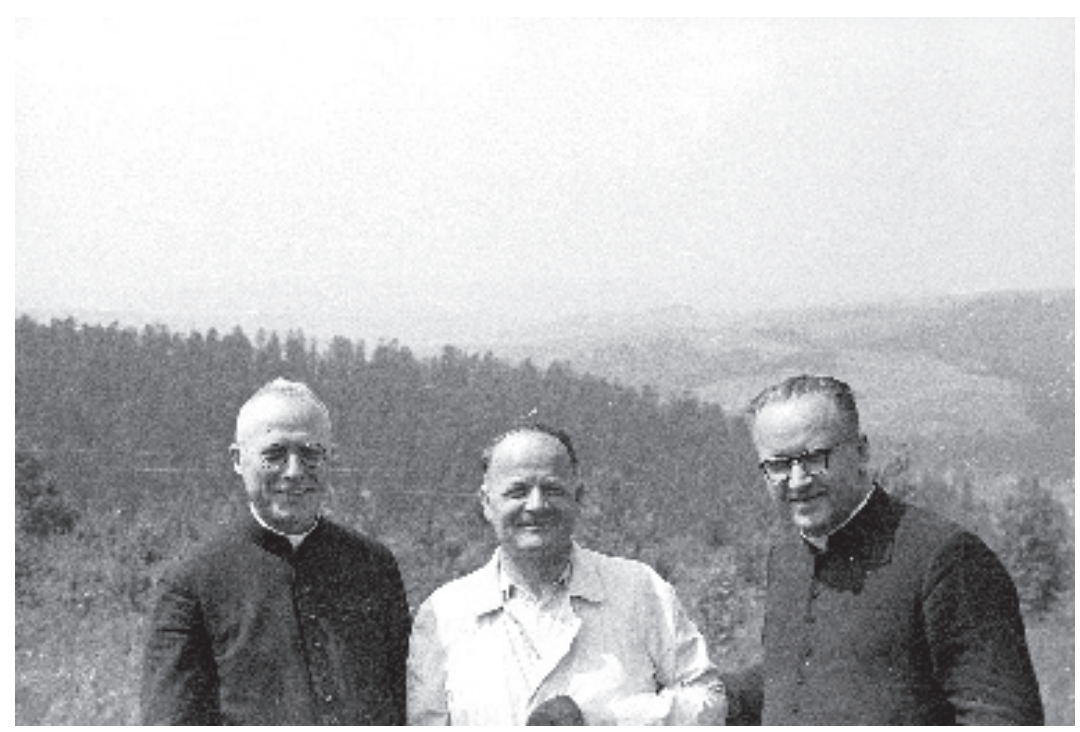

Il. 2. Goście ks. prymasa podczas spaceru. Od lewej: ks. Antoni Porębski, ks. Stanisław Porębski oraz ks. Władysław Porębski z Medyki, Komańcza 1956. Fot. autor nieznany

Źródło: Narodowe Archiwum Cyfrowe, Księża Antoni, Stanisław i Władysław Porębscy podczas odwiedzin prymasa Polski Stefana Wyszyńskiego w Komańczy, sygn. $3 / 43 / 0 / 0 / 61 / 1$ 


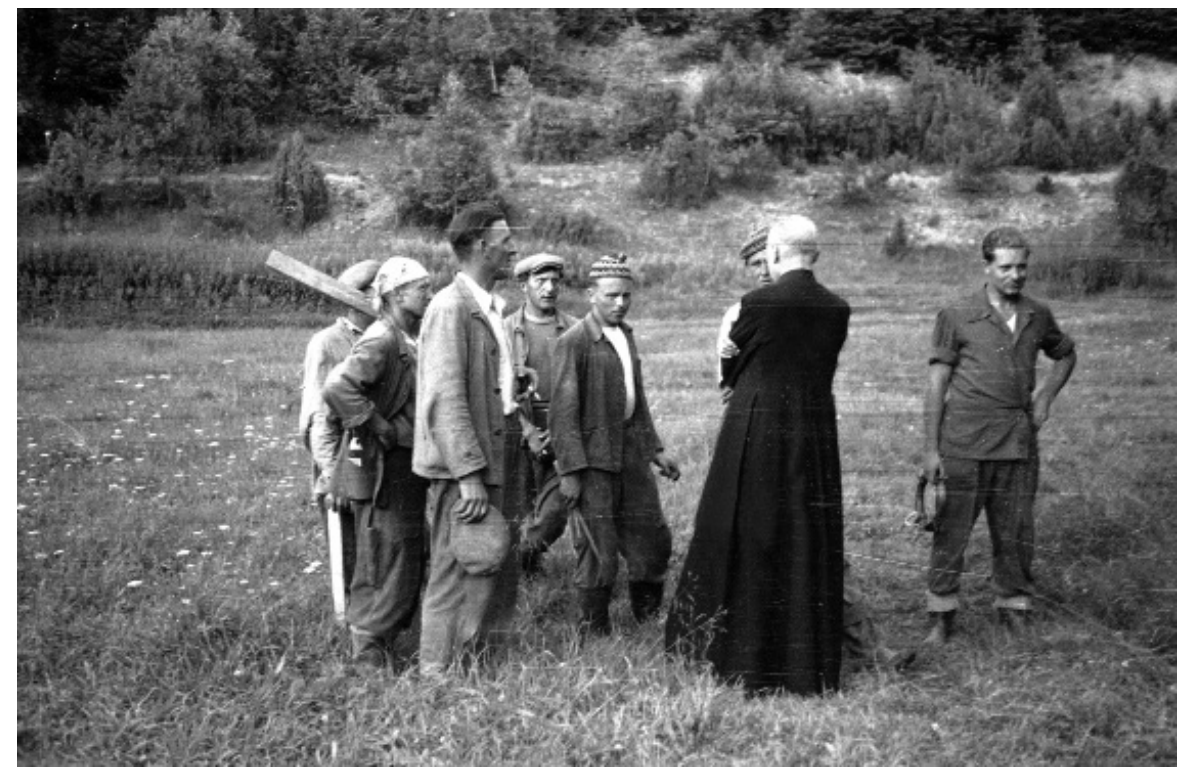

Il. 3. Wycieczka nad jezioro Duszatyń. Ksiądz kard. Stefan Wyszyński rozmawia z robotnikami leśnymi, Duszatyn 1956. Fot. Stanisław Porębski

Źródło: Narodowe Archiwum Cyfrowe, Prymas Polski Stefan Wyszyński podczas internowania w Komańczy, sygn. 3/43/0/0/89/1

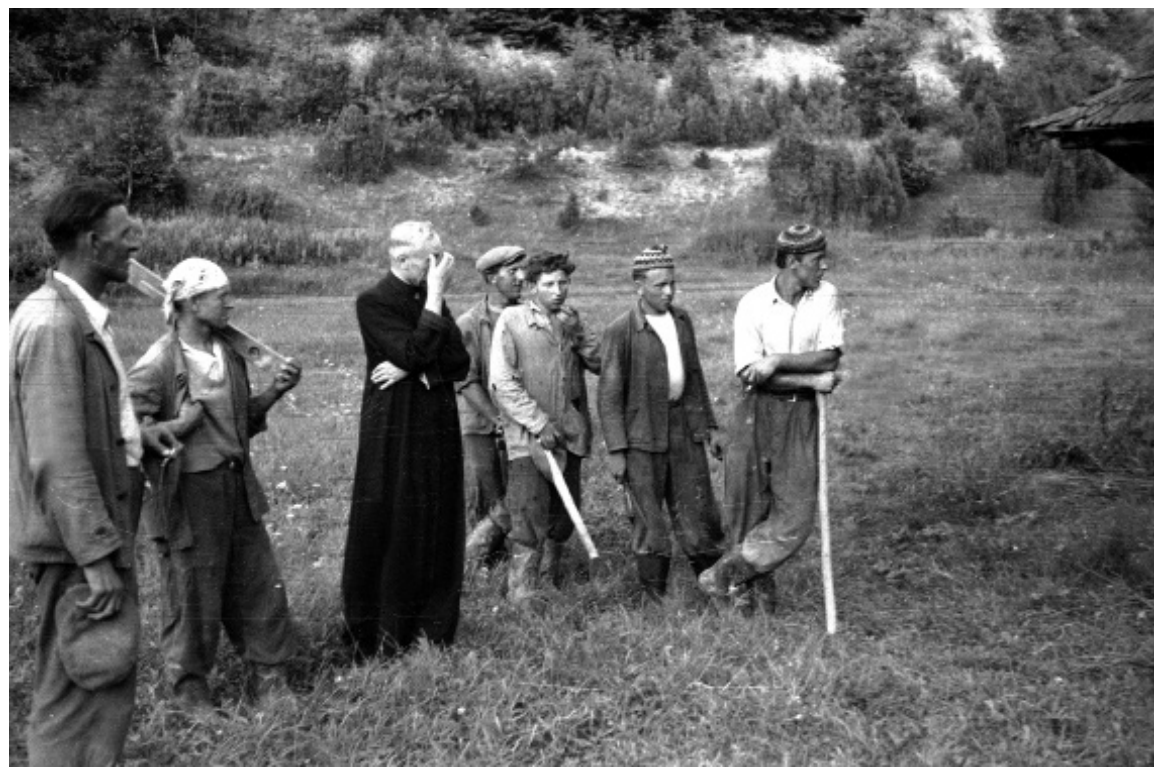

Il. 4. Wycieczka nad jezioro Duszatyń. Kard. Stefan Wyszyński rozmawia z robotnikami leśnymi, Duszatyn 1956. Fot. Stanisław Porębski

Źródło: Narodowe Archiwum Cyfrowe, Prymas Polski Stefan Wyszyński podczas internowania w Komańczy, sygn. 3/43/0/0/90/1 


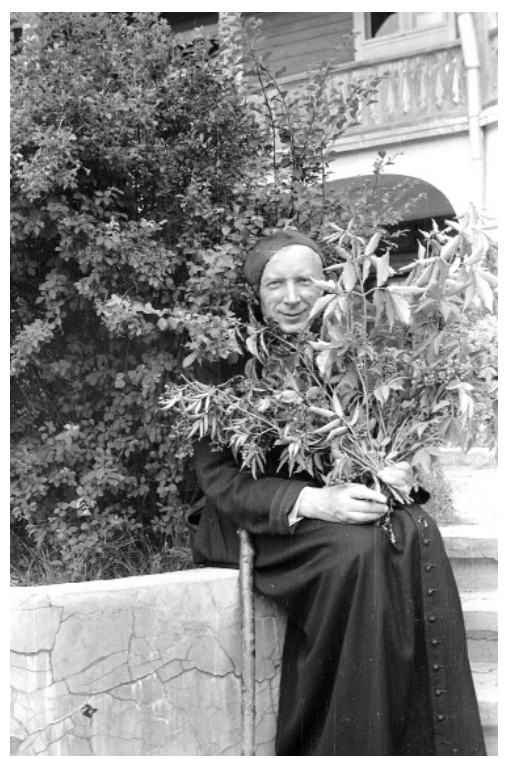

Il. 5. Kard. Stefan Wyszyński przed domem sióstr nazaretanek, Komańcza 1956. Fot. Stanisław Porębski

Źródło: Narodowe Archiwum Cyfrowe, Prymas Polski Stefan Wyszyński podczas internowania w Komańczy, sygn. 3/43/0/0/101/1

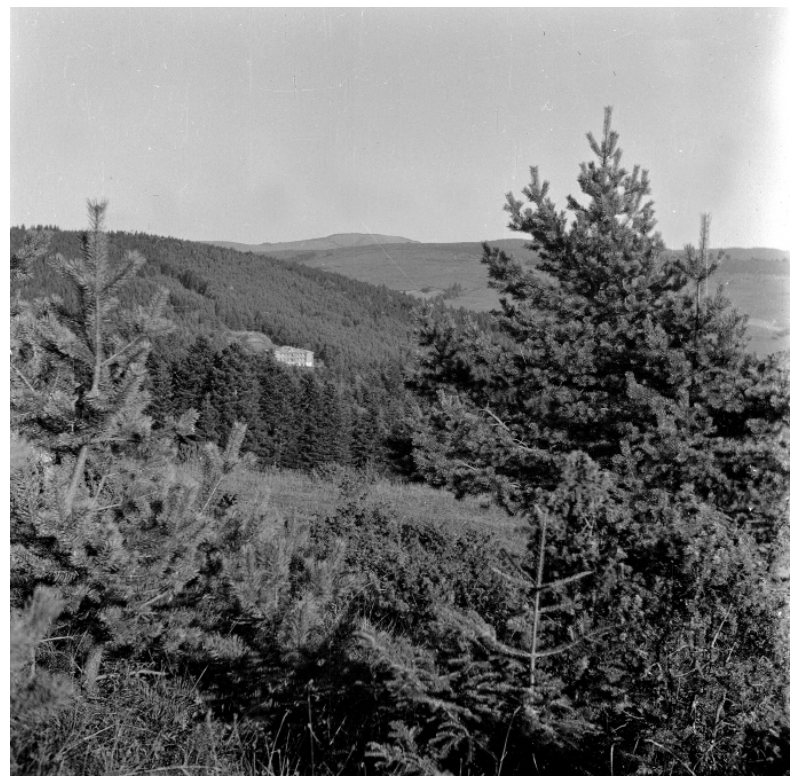

Il. 6. Dom sióstr nazaretanek na tle gór, Komańcza 1956. Fot. Stanisław Porębski

Źródło: Narodowe Archiwum Cyfrowe, Krajobraz okolic Komańczy, sygn. 3/43/0/0/122/1 


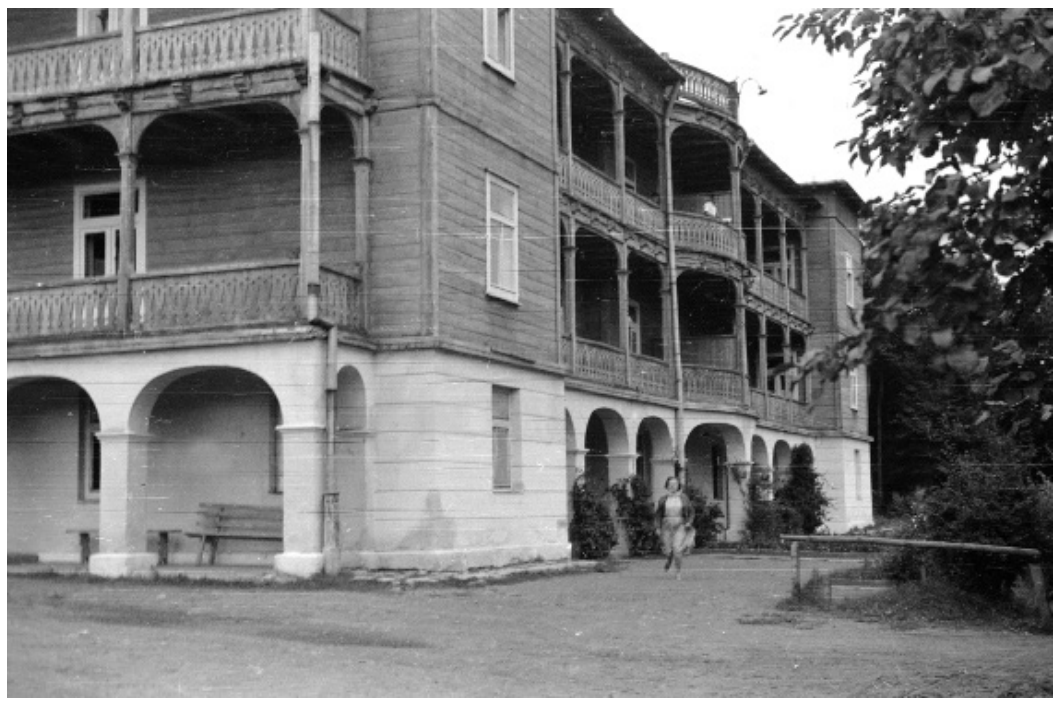

Il. 7. Fragment budynku sióstr nazaretanek, Komańcza 1956.

Fot. Stanisław Porębski

Źródło: Narodowe Archiwum Cyfrowe, Dom sióstr Nazaretanek w Komańczy, sygn. 3/43/0/0/123/1

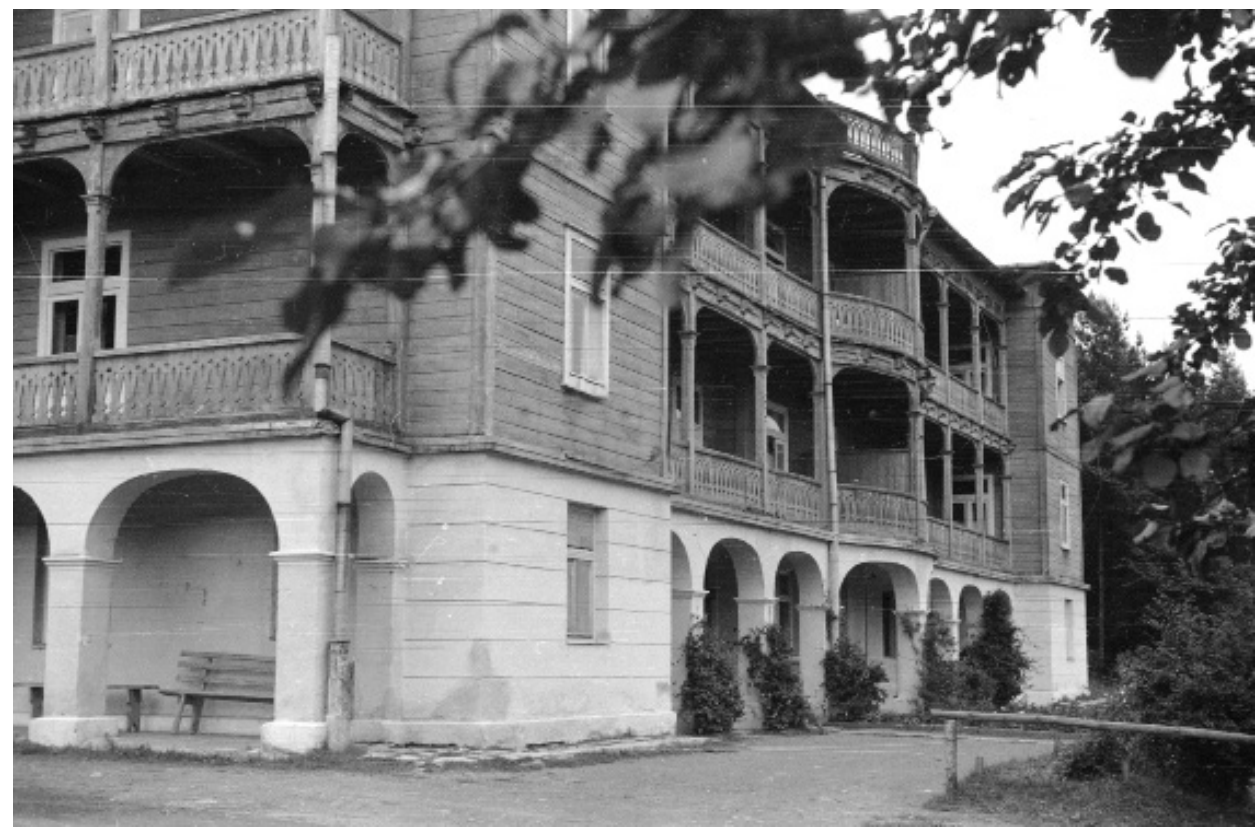

Il. 8. Fragment klasztoru sióstr Nazaretanek, Komańcza 1956. Fot. Stanisław Porębski Źródło: Narodowe Archiwum Cyfrowe, Dom sióstr Nazaretanek w Komańczy, sygn. $3 / 43 / 0 / 0 / 124 / 1$ 


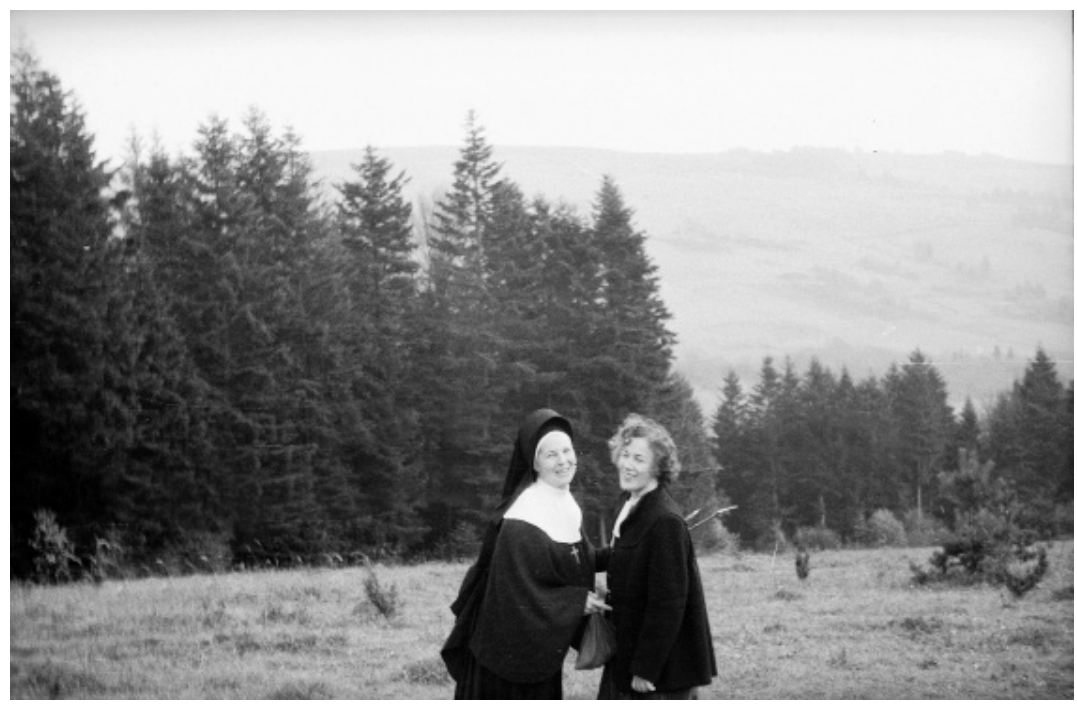

Il. 9. Siostra Narcyza Stankiewicz i Maria Sułek podczas spaceru, Komańcza 1956. Fot. Stanisław Porębski

Źródło: Narodowe Archiwum Cyfrowe, Siostra Narcyza Stankiewicz i Maria Sułek podczas pobytu w Komańczy, sygn. 3/43/0/0/135/1.

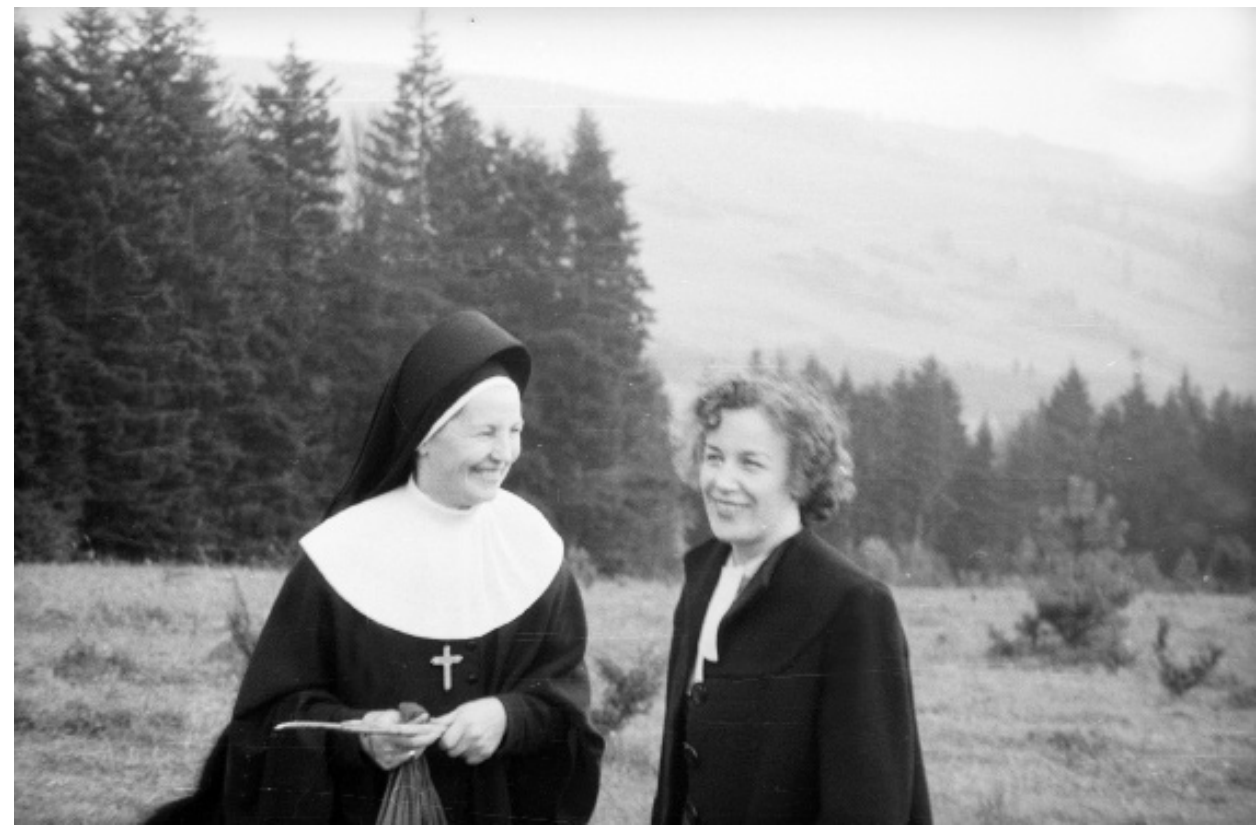

Il. 10. Siostra Narcyza Stankiewicz i Maria Sułek podczas spaceru, Komańcza 1956.

Fot. Stanisław Porębski

Źródło: Narodowe Archiwum Cyfrowe, Siostra Narcyza Stankiewicz i Maria Sułek podczas pobytu w Komańczy, sygn. 3/43/0/0/136/1 


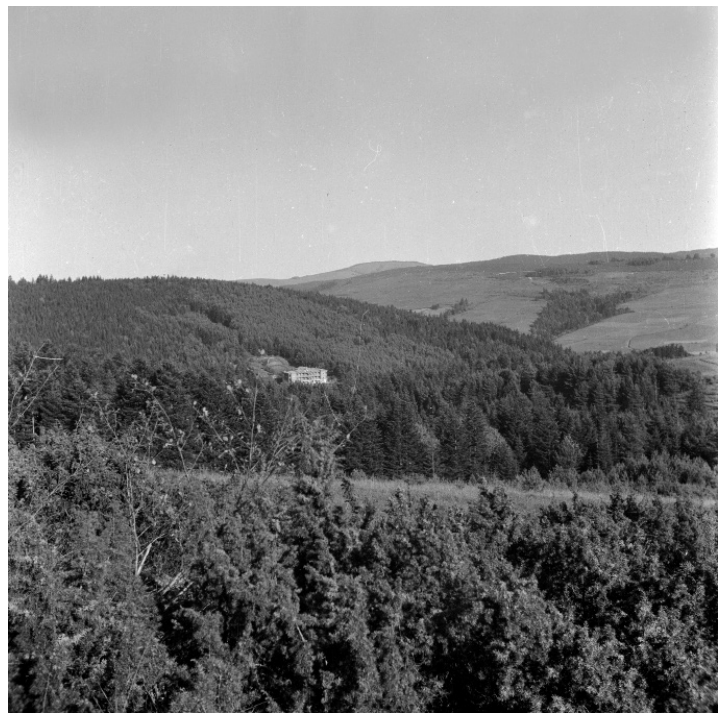

Il. 11. Dom sióstr nazaretanek na tle gór,

Komańcza 1956. Fot. Stanisław Porębski

Źródło: Narodowe Archiwum Cyfrowe, Krajobraz okolic Komańczy, sygn. 3/43/0/0/172/1

3) Zbiór fotografii dotyczących uroczystości beatyfikacyjnych ks. Jerzego Popiełuszki w Warszawie ${ }^{45}$ (2010; nr zespołu 3/76/0) składa się z 1 jednostki archiwalnej zawierającej 57 obiektów fotograficznych. Zdjęcia cyfrowe dokumentują przejście procesji pod kładką dla pieszych w Warszawie. Zostały one wykonane jednego dnia - 6 czerwca 2010 r. Przed rozpoczęciem inwentaryzacji archiwiści musieli dokonać wyboru zdjęć, oceniając ich wartość archiwalną. Kwalifikowali je m.in. ze względu na powtarzalność ujęć, analizując, czy kolejne fotografie wnoszą dodatkowe informacje na temat udokumentowanej ceremonii, czy widoczne na nich transparenty, które stanowiły istotny element treściowy jednostki, są czytelne i ,nieucięte” w kadrach (fot. sygn. 3/76/0/0/1/7, fot. sygn. 3/76/0/0/1/12, fot. sygn. $3 / 76 / 0 / 0 / 1 / 39$, fot. sygn. $3 / 76 / 0 / 0 / 1 / 52)^{46}$.

${ }^{45}$ Zob. https://www.szukajwarchiwach.gov.pl/zespol/-/zespol/55773 (dostęp: 3.10.2021). Zbiór nie został opracowany - na portalu Szukaj w Archiwach dostępny jest tylko elektroniczny inwentarz roboczy.

${ }^{46}$ Współcześnie fotografie cyfrowe wykonywane są na masową skalę. Podczas ich selekcji należy z jednej strony uważać, aby nie zakwalifikować do zasobu archiwalnego zbędnych, bo wielokrotnie powtórzonych lub bardzo podobnych ujęć, z drugiej - nie usunąć tych niewiele się różniących, ale posiadających bogatą warstwę informacyjną, a więc mających wartość archiwalną. Zagadnieniem, o którym warto wspomnieć, jest umożliwienie użytkownikom przeszukiwania utrwalonych na fotografii treści o charakterze pisemnym. W inwentarzu 3/76/0, w opisie każdego ze zdjęć na poziomie obiektu fotograficznego, do pola „Tytuł” przepisano hasła widniejące na niesionych w procesji transparentach. Taka praktyka cytowania nieprzeszukiwalnych treści tekstowych zarejestrowanych na fotografii, przydatna jest dla potrzeb skutecznego dotarcia do informacji. Przygotowanie bardziej rozbudowanego opisu inwentarzowego zabiera więcej czasu, może być jednak satysfakcjonujące dla użytkownika. 


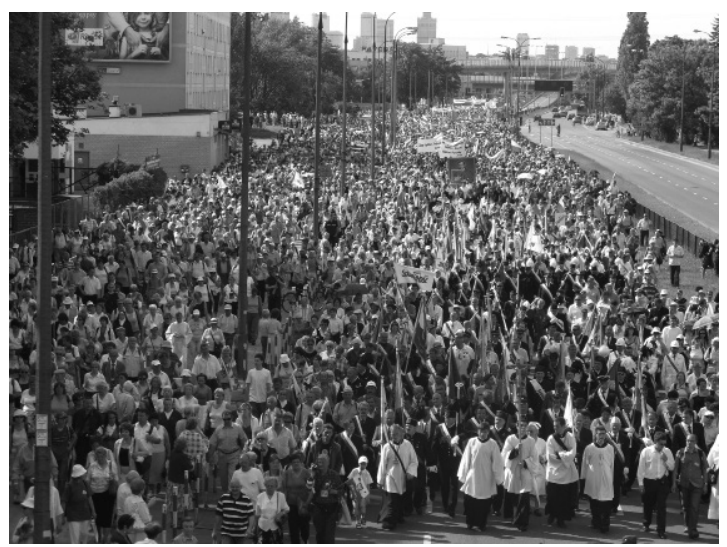

Il. 12. Procesja z relikwiami błogosławionego ks. Jerzego Popiełuszki idąca ulicą Powsińską. Na pierwszym planie widoczni księża i górnicy. W głębi widoczny obraz z wizerunkiem księdza Jerzego towarzyszący niesionym relikwiom, Warszawa 6 czerwca 2010 r. Fot. Nikodem Bończa-Tomaszewski. Źródło: Narodowe Archiwum Cyfrowe, Procesyjne przeniesienie relikwii błogosławionego ks. Jerzego Popiełuszki z pl. J. Piłsudskiego do Świątyni Opatrzności Bożej w Warszawie - procesja przechodząca przez ul. Powsińską róg ul. B. Limanowskiego przy kładce dla pieszych, sygn. $3 / 76 / 0 / 0 / 1 / 7$

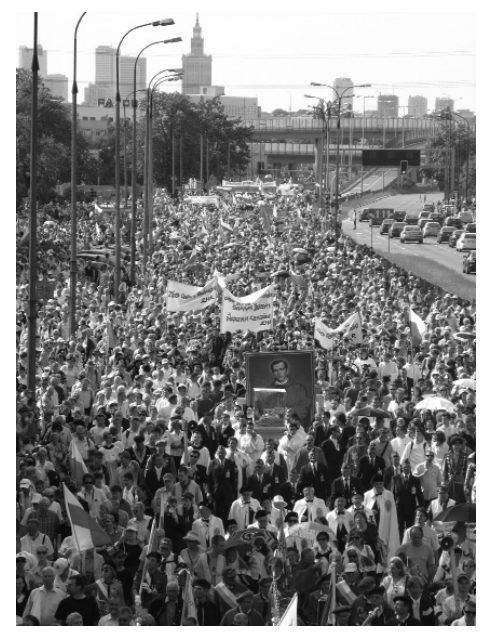

Il. 13. Procesja z relikwiami błogosławionego ks. Jerzego Popiełuszki idąca ulicą Powsińską. Uczestnicy procesji niosą sztandary, flagi narodowe oraz transparenty. Widoczny obraz z wizerunkiem księdza Jerzego towarzyszący relikwiom w szkatule niesionym przez diakonów. Przed relikwiami widoczni dostojnicy kościelni, Warszawa 6 czerwca 2010 r.

Fot. Nikodem Bończa-Tomaszewski

Źródło: Narodowe Archiwum Cyfrowe, Procesyjne przeniesienie relikwii błogosławionego ks. Jerzego Popiełuszki z pl. J. Piłsudskiego do Świątyni Opatrzności Bożej w Warszawie - procesja przechodząca przez ul. Powsińską róg ul. B. Limanowskiego przy kładce dla pieszych, 


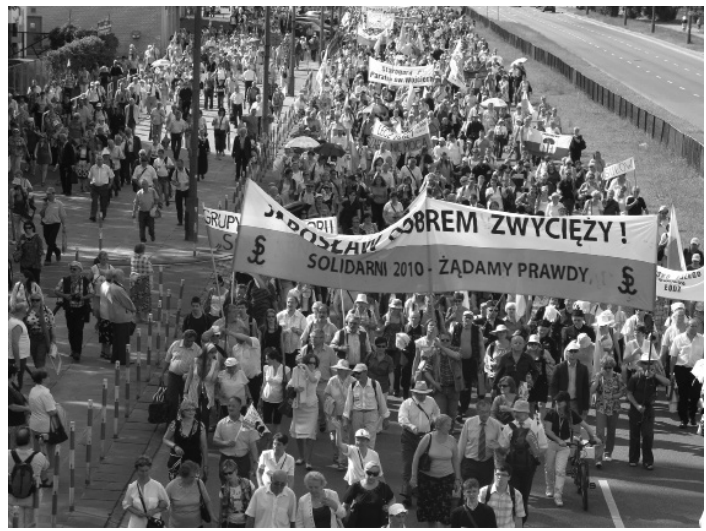

Il. 14. Procesja z relikwiami błogosławionego ks. Jerzego Popiełuszki idąca wzdłuż ulicy Powsińskiej. Widoczni uczestnicy procesji niosący flagi i transparenty o treści: „Jarosław dobrem zwycięży! Solidarni 2010”, „Sułów”, „Lecz duszy zabić nie można. Solidarność Siedlce”, „Starogard Gd. Parafia św. Wojciecha”, „Musimy się na nowo policzyć” „Ratuj Polskę. Limanowa”, „Głosuj na Jarka”, „Solidarność Siedlce”, Warszawa 6 czerwca 2010 r. Fot. Nikodem Bończa-Tomaszewski

Źródło: Narodowe Archiwum Cyfrowe, Procesyjne przeniesienie relikwii błogosławionego ks. Jerzego Popiełuszki z pl. J. Piłsudskiego do Świątyni Opatrzności Bożej w Warszawie - procesja przechodząca przez ul. Powsińską róg ul. B. Limanowskiego przy kładce dla pieszych, sygn. 3/76/0/0/1/39

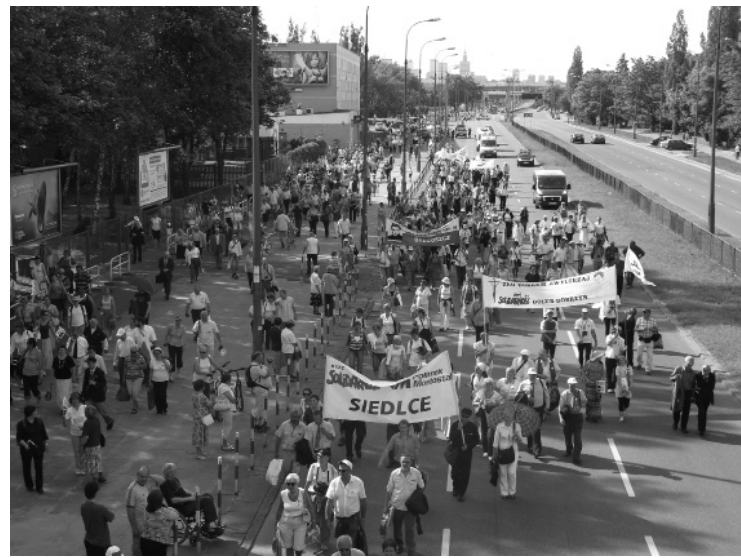

Il. 15. Opis obrazu: Procesja idąca wzdłuż ulicy Powsińskiej. Widoczni uczestnicy procesji niosący flagi i transparenty: „Przebrała się miarka, głosuję na Jarka”, „Solidarność Siedlce. Polimex Mostostal”, „Solidarność Mazowsze”, „Zło dobrem zwyciężaj. Solidarność Golub Dobrzyń”, „Akcja katolicka w Knurowie", Warszawa 6 czerwca 2010 r. Fot. Nikodem Bończa-Tomaszewski Źródło: Narodowe Archiwum Cyfrowe, Procesyjne przeniesienie relikwii błogosławionego ks. Jerzego Popiełuszki z pl. J. Piłsudskiego do Świątyni Opatrzności Bożej w Warszawie - procesja przechodząca przez ul. Powsińską róg ul. B. Limanowskiego przy kładce dla pieszych, sygn. 3/76/0/0/1/52 
4) Zbiór kopii cyfrowych fotografii dotyczących opactwa Benedyktynów w Tyńcu ${ }^{47}$ (1939-1978; nr zespołu 3/78/0), to 383 skany dotychczas nieopracowanych zdjęć. Znajdują się w nim wyłącznie kopie cyfrowe oryginalnych fotografii przechowywanych w Tyńcu. W kolekcji można odnaleźć zdjęcia dokumentujące wizytę kard. S. Wyszyńskiego ${ }^{48}$ w opactwie. Są wartościowe z powodów dokumentacyjnych, niestety charakteryzują się niskimi parametrami technicznymi. Ich niedostateczna jakość dotyka m.in. osoby planujące ich wykorzystanie w celach wydawniczych. Użytkownicy chcący uzyskać zadowalające parametry kopii cyfrowych są więc kierowani do miejsca przechowywania oryginałów. Kolejny etap kontaktu z instytucjami wydłuża jednak cały proces pracy. Jest to więc jeden $\mathrm{z}$ argumentów, świadczący o priorytecie pozyskiwania oryginalnych fotografii do zasobu archiwum również po to, aby w razie konieczności przygotować kopie cyfrowe o lepszej jakości.

5) Kolekcja Mariana Romaniuka dotycząca prymasa Polski kard. Stefana Wyszyńskiego ${ }^{49}(1917-2001$; nr zbioru 3/82/0) zawiera wyłącznie odbitki pozytywowe. Zbiór nie jest opracowany. Materiały zdigitalizowano, przygotowano do nich ewidencję według porządku nadanego przez autora kolekcji i przy wykorzystaniu sporządzonych przez niego opisów. Dzięki szczegółowemu spisowi roboczemu ${ }^{50}$ istnieje możliwość sprawnego dotarcia do poszukiwanych obiektów fotograficznych. Kolekcja Mariana Romaniuka dotycząca prymasa Polski kard. S. Wyszyńskiego to zbiór bogato dokumentujący życie S. Wyszyńskiego. Niestety Narodowe Archiwum Cyfrowe nie posiada autorskich praw majątkowych do większości fotografii. Dzięki zapisaniu przez kolekcjonera nazwisk autorów zdjęć istnieje jednak szansa na pozyskanie praw od autorów lub ich spadkobierców, a w efekcie - wykorzystanie zebranych tu materiałów.

Zdjęcia o tematyce kościelnej nie tylko tworzą samodzielne zespoły lub zbiory w zasobie fotograficznym Narodowego Archiwum Cyfrowego. Można je również odnaleźć m.in. w archiwach agencji fotograficznych z okresu przedi powojennego. W zespole nr 3/1/0 Koncern Ilustrowany Kurier Codzienny Archiwum Ilustracji (1910-1939) ${ }^{51}$, w serii nr 15 Wyznania religijne ${ }^{52}$ zebrano fotografie dokumentujące tę tematykę. Usystematyzowano je według związków wyznaniowych, 1062 jednostki dotyczą Kościoła katolickiego ${ }^{53}$. W serii tej znalazły się m.in.: portrety duchownych, uroczystości religijne (Msze św., również

${ }^{47}$ Zob. https://www.szukajwarchiwach.gov.pl/zespol/-/zespol/55775 (dostęp: 3.10.2021).

${ }^{48}$ Są to 43 fotografie fotoreporterskie.

${ }^{49}$ Zob. https://www.szukajwarchiwach.gov.pl/zespol/-/zespol/55778 (dostęp: 3.10.2021).

${ }^{50}$ Spis roboczy jako środek ewidencyjny, wymieniony w zarządzeniu nr 7 Naczelnego Dyrektora Archiwów Państwowych z dnia 30 stycznia 2018 r., par. 8, ust. 3 pkt 10.

${ }^{51}$ Zob. https://www.szukajwarchiwach.gov.pl/zespol?p_p_id=Zespol\&p_p_lifecycle=1\&p_p_ state $=$ normal\&p_p_mode $=$ view\&_Zespol_javax.portlet.action=zmienWidok\&_Zespol_id_zespolu=55702 (dostęp: 3.10 .2021$)$.

${ }^{52}$ Zob. https://www.szukajwarchiwach.gov.pl/seria?p_p_id=Seria\&p_p_lifecycle=0\&p_p_state $=$ normal\&p_p_mode $=$ view\&_Seria_delta $=20 \& \_S e r i a \_n a m e o f j s p=j e d n o s t k i \&$ Seria_resetCu$\mathrm{r}=$ false\&_Seria_id_serii $=302584 \&$ Seria_cur $=1$, (dostęp: 3.10 .2021$)$.

${ }^{53}$ Archiwum Dokumentacji Mechanicznej, s. 65. 
żałobne), zgromadzenia episkopatu Polski, jubileusze, ingresy biskupie i inne. Materiały dokumentujące tematykę kościelną w okresie po 1945 r. znajdują się w zespole 3/4/0 Centralna Agencja Fotograficzna (1944-1992) ${ }^{54}$. Zespół nie jest jeszcze opracowany, jednak na portalu Szukaj w Archiwach można przeglądać roboczy inwentarz liczaccy ponad 320 tys. jednostek archiwalnych ${ }^{55}$. Odnalezienie w nim materiałów jest możliwe po wpisaniu do wyszukiwarki słów kluczowych (np. „Wyszyński”). Z uwagi na oficjalny charakter tej państwowej agencji, zrealizowane serwisy fotograficzne dotyczyły wyłącznie wydarzeń zaakceptowanych przez cenzurę i oficjalne władze.

Wśród zespołów i zbiorów o tematyce kościelnej przechowywanych w Narodowym Archiwum Cyfrowym nie ma opracowanych wyłącznie według wskazówek metodycznych wprowadzonych w latach 2018-2019. Jedyny, przy którym trwają prace melioracyjne, mające na celu dostosowanie go do obowiązujących zarządzeń, to Zbiór fotografii dotyczących obchodów kościelnych Tysiąclecia Chrztu Polski. Przedstawione fotografie i wiele innych można obejrzeć na portalu Szukaj w Archiwach ${ }^{56}$. Swoje zasoby publikują tutaj archiwa państwowe oraz inne instytucje, w tym instytucje kościelne, korzystające nieodpłatnie ze Zintegrowanego Systemu Informacji Archiwalnej ${ }^{57}$.

\section{REFERENCES / BIBLIOGRAFIA}

\section{Źródla}

Decyzja nr 8 Naczelnego Dyrektora Archiwów Państwowych z dnia 24 kwietnia 2006 r. w sprawie wprowadzenia wskazówek metodycznych dotyczących zasad opracowania fotografii w archiwach państwowych, zmieniona decyzją Nr 16 Naczelnego Dyrektora Archiwów Państwowych z dnia 25 lipca 2006 r., https://www.archiwa.gov.pl/images/docs/akty normatywne/Dec 8 2006.pdf (dostęp: 4.12.2021).

Inwentarz zbioru Tysiaclecie Chrztu Polski [Obchody kościelne], oprac. A. Potemkowska, Warszawa [b.r., mps].

Uchwała Sejmu Rzeczypospolitej Polskiej z dnia 27 listopada 2020 r. w sprawie ustanowienia roku 2021 Rokiem Kardynała Stefana Wyszyńskiego, M.P. z 2020 r. poz. 1156, http://orka.sejm.gov.pl/proc9.nsf/uchwaly/624_u.htm (dostęp: 4.12.2021).

Zarządzenie nr 3 z dnia 26 stycznia 1974 r. Naczelnego Dyrektora Archiwów Państwowych w sprawie sporządzania indeksów do inwentarzy archiwalnych, https://www. archiwa.gov.pl/files/zarzadzenia_NDAP/zarz3_1974.pdf (dostęp: 3.10.2021).

${ }^{54}$ 3/4/0 Centralna Agencja Fotograficzna (1944-1992), https://www.szukajwarchiwach.gov.pl/ zespol/-/zespol/55705 (dostęp: 4.2.2021).

${ }^{55}$ Inwentarz jest dostępny na portalu Szukaj w Archiwach, https://www.szukajwarchiwach.gov. $\mathrm{pl} /$ zespol?p_p_id $=$ Zespol\&p_p_lifecycle $=1 \& \mathrm{p} \_\mathrm{p} \_$state $=$normal\&p_p_mode $=$view\&_Zespol_javax.portlet.action=zmienWidok\&_Zespol_nameofjsp=jednostki\&_Zespol_id_zespolu=55705 (dostęp: 4.12.2021).

${ }^{56}$ Szukaj w Archiwach, https://www.szukajwarchiwach.gov.pl/ (dostęp: 3.10.2021).

${ }^{57}$ Dołączenie do tego systemu jest stale możliwe. W tym celu należy kontaktować się z Oddziałem Archiwistyki Cyfrowej w Narodowego Archiwum Cyfrowego, np. za pośrednictwem e-maila: oac@nac.gov.pl. 
Zarządzenie nr 7 Naczelnego Dyrektora Archiwów Państwowych z dnia 30 stycznia 2018 r. w sprawie ewidencjonowania zasobu archiwalnego w archiwach państwowych, https://www.archiwa.gov.pl/files/zarzadzenia_NDAP/zarz7_2018.pdf (dostęp: 3.10.2021).

Zarządzenie nr 8 Naczelnego Dyrektora Archiwów Państwowych z dnia 30 stycznia 2018 r. w sprawie inwentaryzacji materiałów archiwalnych oraz sporządzania i zatwierdzania elektronicznych inwentarzy archiwalnych dla zespołów (zbiorów) w archiwach państwowych, https://www.archiwa.gov.pl/files/zarzadzenia_NDAP/zarz8_2018.pdf (dostęp: 3.10.2021).

Zarządzenie nr 14 Naczelnego Dyrektora Archiwów Państwowych z dnia 31 sierpnia 2015 r. w sprawie digitalizacji zasobu archiwalnego archiwów państwowych, https://www. archiwa.gov.pl/images/docs/akty_normatywne/zarz_14-2015.pdf (dostęp: 3.10.2021).

Zarządzenie nr 34 Naczelnego Dyrektora Archiwów Państwowych z dnia 9 września 2019 r. w sprawie zasad porządkowania i inwentaryzacji dokumentacji fotograficznej w archiwach państwowych, https://ndap.bip.gov.pl/dziennik-urzedowy/dziennik-urzedowy-2019.html (dostęp: 3.10.2021).

\section{Opracowania}

Archiwum Dokumentacji Mechanicznej. Przewodnik po zasobie fotografii 1840-2004, oprac. J. Boniecki, Warszawa 2005.

\section{Netografia}

Narodowe Archiwum Cyfrowe, Lista zespołów, https://www.szukajwarchiwach.gov.pl/ web/narodowe-archiwum-cyfrowe/zespoly (dostęp: 3.10.2021).

Niepodległa Poddębskiego, Warszawa 2017, https://www.nac.gov.pl/wp-content/ uploads/2017/11/NAC-Henryk-Poddebski-eBook.pdf (dostęp: 4.12.2021).

PRL Rutowskiej. Fotografie z Narodowego Archiwum Cyfrowego, Warszawa 2015, https:// www.nac.gov.pl/pub/PRL_Rutowskiej/mobile/index.html (dostęp: 4.12.2021).

Warszawa Siemaszki. Fotografie z Narodowego Archiwum Cyfrowego, Warszawa 2014, https:// www.nac.gov.pl/pub/Warszawa_Siemaszki/mobile/index.html (dostęp: 4.12.2021).

Witczak-Witaczyński Narcyz, Warszawa 2016, https:/www.nac.gov.pl/pub/Narcyz_Witczak-Witaczynski/mobile/index.html\#p=1 (dostęp: 4.12.2021).

Wojciech Tuszko - fotograf, Warszawa 2020, https://www.nac.gov.pl/wp-content/uploads/2015/05/ nac-TUSZKO-1.0.1-www.pdf (dostęp: 4.12.2021). 


\title{
ARCHIVAL DEVELOPMENT OF PHOTOGRAPHS IN NATIONAL DIGITAL ARCHIVES: CASE STUDIES ON EXAMPLES OF FONDS AND COLLECTIONS ON CHURCH TOPICS
}

\begin{abstract}
The holdings of National Digital Archives include photographs taken and collected by photo agencies, Polish leading professional photographers, photojournalists and amateur photographers. Photographs stored in archive can be a separate groups and can be also parts of other fonds of files. In my article I will discuss the topic of archival fonds (collections) containing only photographic documentation.

The methods of proceeding with archival materials are regulated by normative acts of the director of the Head Office of the State Archives: directive no. 7 of 30 January 2018 regarding registration of archival holdings in state archives and also directive no. 8 of 30 January 2018 about registration of archival fonds and creating and accepting of inventories for fonds (collections) in state archives. The directive no. 3 of NDAP of 9 September 2019 regarding rules of archival arrangement and developing of photographic documentation in state archives orders especially the method of processing of photographs.

Photographic collections should have records. When the condition of photographs raises doubts, and also makes troubles during digitalization, it's required to consult qualified conservator and, if needed, perform conservation. Recording and digitalization, with simultaneous repackaging to protective packaging are the next steps of work on archival fond (collection). Also the archival value of processed materials is rated during those works. The introduction to archival inventory contains information complementary to possessed knowledge about materials in fond (collection) and about their author (maker of collection). For all those works is best to use Integrated System of Archival Information (Zintegrowany System Informacji Archiwalnej, ZOSIA).

In National Digital Archives are stored archival fonds and collections regarding church topics. In my article they are discussed due to interesting content, method of archival developing and description, issues of copyright and possibilities of further usage by users of archival holdings and rating of archival value. Those fonds are mainly: 3/19/0 Collection of photos regarding church celebrations of Millennium of Polish Baptism, 3/43/0 Photographic archive of Stanisław Porembski, 3/76/0 Collection of photos regarding beatification celebration of priest Jerzy Popiełuszko in Warsaw, 3/78/0 Collection of digital copies of photos regarding Benedictine abbey in Tyniec, 3/82/0 Collection of Marian Romaniuk regarding Primate of Poland cardinal Stefan Wyszyński.
\end{abstract}

Keywords: photographic documentation, photographs; archival photographs, processing of photographs, photographic archive, inventarisation of photographs, archival unit, photographic object, copyright, rating of archival value 